\title{
Stability of volatile profile and sensory properties of passion fruit juice during storage in glass bottles
}

\author{
Estabilidade do perfil de voláteis e propriedades sensoriais \\ de suco de maracujá durante estocagem em garrafas de vidro
}

\author{
Vitória Matos de FREITAS ${ }^{1}$, Deborah dos Santos GARRUTI ${ }^{2 *}$, Manoel Alves SOUZA NETO², \\ Heliofábia Virgínia de Vasconcelos FACUNDO ${ }^{1}$, José Maria CORREIA ${ }^{1}$
}

\begin{abstract}
This study aimed at assessing the stability of passion fruit juice in glass bottles during a 120-day storage period, regarding its volatile compounds profile and sensory properties (aroma and flavor). Samples were obtained from a Brazilian tropical juice industry (Fortaleza, Brazil) and submitted to sensory and chromatographic analyses. The characteristic aroma and flavor of passion fruit were evaluated by a trained panel with a non-structured scale of $9 \mathrm{~cm}$. The headspace volatile compounds were isolated from the product by suction and trapped in Porapak Q, analyzed through high-resolution gas chromatography and identified through gas chromatography-mass spectrometry (GC-MS). Twelve odoriferous compounds were monitored: ethyl butanoate, ethyl propanoate, 3-methyl-1-butanol, 3-methyl-2-butenol, (E)-3-hexenol, (Z)3-hexenol, 3-methylbutyl acetate, benzaldehyde, ethyl hexanoate, hexyl acetate, limonene and furfural. The slight variations observed in the volatile profile were not enough to provoke significant changes in the characteristic aroma and flavor of the passion fruit juice.

Keywords: Passiflora; tropical juice; packaging material; volatile compounds; sensory analysis; storage.
\end{abstract}

\section{Resumo}

O objetivo deste estudo foi avaliar a estabilidade do suco de maracujá em garrafas de vidro durante 120 dias de estocagem, em relação ao perfil de compostos voláteis e características sensoriais (aroma e sabor). As amostras foram obtidas em uma indústria brasileira de sucos tropicais e submetidas a análises sensoriais e cromatográficas. O aroma e sabor característicos de maracujá foram analisados por uma equipe de julgadores treinados, por meio de uma escala não estruturada de $9 \mathrm{~cm}$. Os compostos voláteis do headspace foram isolados do produto por sucção e capturados em armadilhas de Porapak Q, analisados por cromatografia gasosa de alta resolução e identificados por CG-espectrometria de massas. Doze compostos voláteis foram monitorados: butanoato de etila, propanoato de etila, 3-metil-1-butanol, 3-metil-2-butenol, (E)-3-hexenol, (Z)-3-hexenol, 3-acetato de metilbutila, benzaldeido, hexanoato de etila, acetate de hexila, limoneno e furfural. As pequenas variações observadas no perfil de voláteis não foram suficientes para provocar alterações significativas no aroma e sabor do suco de maracujá. Palavras-chave: Passiflora; suco tropical; material de embalagem; compostos voláteis; análise sensorial; estocagem.

\section{Introduction}

The genus Passiflora, with over 500 species, is native from South America and it has Brazil's central-northern region as its main geographical distribution center. The plant is widely known due to its fruit, called "passion fruit", which presents an exotic flavor and also a high nutrition value, including pro-vitamin A, niacine, riboflavine and ascorbic acid. Native Brazilians of Tupi origin used to call it "mara kuya", which in a literal translation can be understood as "food in the shape of a bowl" and then "maracuja" in Portuguese (BAHIA, 2007).

Brazil is the largest producer of passion fruit in the world with more than 35,000 ha of cultivated area and 485 thousand tons of fruit (GONÇALVES; SOUZA, 2006). Kenya and other African countries export in natura fruit, while juices and pulps are produced by Brazil, Colombia, Peru, Ecuador, Venezuela, Costa Rica, among others (BAHIA, 2008). Passiflora edulis Sims f. flavicarpa Deg. - or yellow passion fruit is the most important species cultivated in Brazil, corresponding to 95\% of the planted area. The fruit has a yellow peel and guards inside it a juicy flesh full of seeds, commonly used in the production of juices. More than half of the world production is exported in the form of concentrate juice (FERRARI et al., 2004), but in Brazil, the most popular product is a mix of pulp and concentrate juice, packed in glass bottles.

Changes in aroma compounds during storage are due to storage time and temperature, oxygen content, light exposure, container interaction and chemical contamination (GRAUMLICH et al., 1986). Glass is considered an inert packaging material, not causing problems related to migration of compounds, i.e. does not transfer foreign flavors to the food neither absorbs compounds from the food matrix. It is also impermeable to gases and vapors, once its integrity and tightness are assured by appropriate capping. However, most

Received 16/4/2009

Accepted 23/1/2010 (004155)

${ }^{1}$ Departamento Tecnologia de Alimentos, Universidade Federal do Ceará - UFC, CEP 60356-000, Fortaleza - CE, Brasil

2 Tecnologia de Alimentos, Embrapa Agroindústria Tropical, Rua Dra. Sara Mesquita, 2270, Planalto do Pici, CEP 60511-110, Fortaleza - CE, Brasil

${ }^{*}$ Corresponding author 
closure systems use plastic caps, which can result in some degree of migration. Moreover, glass allows the passage of light, especially if it does not receive the addition of pigments (AZEREDO, 2004).

Of all these factors, storage temperature is the most important (GRAUMLICH et al., 1986). In Brazil, the room temperature is high, especially in the Northeastern region. In this context, the aim of the present study was to investigate the stability of the volatile profile and sensory characteristics (aroma and flavor) of passion fruit juice stored in glass bottles, simulating the conditions that this product is submitted to in general supermarkets and grocery stores.

\section{Materials and methods}

\subsection{Material}

Commercial passion fruit juice, bottled in $500 \mathrm{~mL}$ glass bottles were obtained from a large scale Brazilian tropical juice industry. The ingredients of the bottled juice were: passion fruit pulp (min. 60\%), water, concentrate passion fruit juice and additives - sodium metabisulfite, sodium benzoate, citric acid, pectin, xanthan gum and flavoring identical to natural passion fruit. Ingredients were homogenized, pasteurized and hot-filled in glass bottles.

Bottles were stored for 120 days on display shelves simulating general storage conditions used in supermarkets and grocery stores: $24 \pm 1^{\circ} \mathrm{C}$ by 12 hours, acclimatized ambient, followed by $12 \mathrm{~h}$ at $26 \pm 2{ }^{\circ} \mathrm{C}$, during store's closure.

Samples were submitted to sensory analyses at zero time storage and at every 30 days. The headspace volatile profile was examined at zero time and at every 60 days.

\subsection{Sensory analysis}

Selection of panel members started with fifteen individuals, all of them with a long experience in sensory analysis. Six 1-h training sessions were carried out until they were able to recognize and rate the aroma and flavor of fresh passion fruit juice. To evaluate the panel performance, panelists assessed the intensity of the fresh passion fruit characteristic aroma and flavor of three samples, in continuous unstructured scales of $9 \mathrm{~cm}$, anchored "not perceptible" at the low end and "equal to standard" at the high end (MEILGAARD et al., 1999). Standard sample was fresh home made passion fruit juice. Samples to be analyzed included two commercial brands and the standard sample. All the samples were prepared as to obtain total soluble solids content of approximately $2{ }^{\circ} \mathrm{Brix}$. Thirty milliliters were served at $21{ }^{\circ} \mathrm{C}\left( \pm 2^{\circ} \mathrm{C}\right)$, in tulip-shaped glasses covered with Petri dishes, identified by three-digit random codes.

Panelists were individually checked for abilities in discriminating the samples (high F values, $\mathrm{p}_{\text {samples }}<0.30$ ) and providing repeatable results $\left(\mathrm{p}_{\text {repetition }}>0.05\right)$ two-way ANOVA (samples and repetition) for each attribute, as well as their consensus with the other members of the group, according to the methodology proposed by Damásio and Costell (1991). Homogeneity in the group was also tested by two-way ANOVA for each attribute (main effect panelists and samples) and the training was considered to be concluded when none panelists $x$ samples interaction was found. The sensory panel was then composed of five females and four males, 20-55 years of age.

Measurements of the stability experiment were performed every 30 days, in triplicates, for aroma and flavor descriptors, with the same unstructured 9-cm scale and the same standard sample used during training and selection, described above. The sensory data was submitted to statistical analyses by the Statistical Analysis System (SAS), Version 8 (Cary, USA). Analysis of variance was performed by GLM procedure and means were tested by REGWq method. Regression analysis, when necessary, was performed by the RSREG procedure.

\subsection{Volatile compounds analysis}

The aroma compounds were obtained by a dynamic headspace sampling technique (FRANCO; RODRIGUEZAMAYA, 1983). After the addition of $30 \% \mathrm{w} / \mathrm{w} \mathrm{NaCl}, 250 \mathrm{~g}$ of juice were put into a volatile collecting device. The compounds from passion fruit juice headspace were swept by vacuum to a Porapak Q trap 80-100 mesh (Waters-Associates) for 2 hours and then eluted with $300 \mu \mathrm{L}$ of dichloromethane. The eluted material was called "isolate". The polymer was previously conditioned by heating at $180{ }^{\circ} \mathrm{C}$ for $24 \mathrm{~h}$ with the passage of pure nitrogen at $30 \mathrm{~mL} /$ minutes.

Volatile constituents were separated on a Varian CP-Sil 8CB fused silica capillary column $(30 \mathrm{~m} \times 0.25 \mathrm{~mm}$ i.d., $0.25 \mu \mathrm{m}$ film thickness), using a Varian CP 3800 (USA) gas chromatograph with a flame ionization detector (FID). $1 \mu \mathrm{L}$ of the isolate was injected in the splitless mode. The oven temperature was programmed from $30^{\circ} \mathrm{C}$ to $150^{\circ} \mathrm{C}\left(3^{\circ} \mathrm{C} /\right.$ minutes $)$ and then to $220^{\circ} \mathrm{C}\left(20^{\circ} \mathrm{C} /\right.$ minutes $)$. Injector and detector were maintained at $250{ }^{\circ} \mathrm{C}$. Hydrogen was the carrier gas at a flow rate of $1.5 \mathrm{~mL} /$ minutes. Analyses were made in triplicates.

Compounds were identified in a Shimadzu model GC-2010 gas chromatograph (Kyoto, Japan) coupled to a Shimadzu model QP-2010 mass spectrometer (GC/MS) at an ionization voltage of $70 \mathrm{eV}$ and $1 \mathrm{scan} / \mathrm{seconds} \mathrm{MS}$ scan range. Two capillary columns of different polarities were used: a non polar (J\&W DB-5MS $30 \mathrm{~m} \times 0.25 \mathrm{~mm}$ i.d., $0.25 \mu \mathrm{m}$ film thickness) and a semi-polar (J\&W DB-wax $30 \mathrm{~m} \times 0.25 \mathrm{~mm}$ i.d., $0.25 \mu \mathrm{m}$ film thickness). The temperature program was the same as described for the volatile compounds separation. Helium was the carrier gas at a flow rate of $1.0 \mathrm{~mL} /$ minutes. A standard mixture of $\mathrm{n}$-alkanes (C8-C20) was injected to determinate linear retention indices. The identification of the volatile compounds was based on the comparison of mass spectra of unknown compounds against NIST 98 MS library data for the GC-MS and experimental and theoretical retention indices.

\section{Results and discussion}

Table 1 presents the volatile compounds detected in the headspace of passion fruit juice stored in glass bottles for 120 days. Forty volatile compounds were detected by FID and thirty-nine were identified by CG-MS. The numerical grouping of these various components, according to their chemical family, 
showed a wide diversity: esters $(\mathrm{n}=10)$, alcohols $(\mathrm{n}=8)$, terpenes $(n=7)$, ketones $(n=4)$, carboxylic acids $(n=4)$, aldehydes $(\mathrm{n}=3)$ and hydrocarbons $(\mathrm{n}=2)$.

Esters were the main chemical class in these passion fruit juice samples, comprising more than $90 \%$ of the chromatogram area. Ethyl butyrate predominated in the samples, corresponding to more than $80 \%$ of the total area. Chen et al. (1982) detected 33 esters in three different varieties of passion fruit and found ethyl butyrate to be the major compound (35\%) in the purple variety.
Ethyl butyrate was also found among the major compounds by Narain et al. (2004) and Jales et al. (2005) who reported 8.3\% and $43.3 \%$, respectively, for this compound, but neither author found so much percentage of ethyl butyrate. This great difference may be due to the fact that the analyzed product was flavored with a flavoring claimed to be "identical to natural passion fruit", but we really did not have access to this product's composition. Other esters that could also be considered as major compounds were: ethyl propanoate (5.66\%), and ethyl hexanoate (1.16\%). Ethyl hexanoate was also considered a major compound by

Table 1. Compounds identified by GC/MS in the headspace of passion fruit juice stored in glass containers during 120 days (Descriptors according to literature).

\begin{tabular}{|c|c|c|c|c|c|c|}
\hline \multirow[t]{3}{*}{ Peak } & \multirow[t]{3}{*}{ Compound } & \multirow[t]{3}{*}{ RI DB-5 } & \multirow[t]{3}{*}{ Descriptors $\Psi$} & \multicolumn{3}{|c|}{ Area \% } \\
\hline & & & & \multicolumn{3}{|c|}{ Time in days } \\
\hline & & & & 0 & 60 & 120 \\
\hline 1 & Pentanal & $<800$ & - & $\operatorname{tr}$ & nd & $\operatorname{tr}$ \\
\hline 2 & 3- hidroxy-2-butanone & $<800$ & Merthyolate $^{\mathrm{a}}$, fermented ${ }^{\mathrm{b}}$, & $\operatorname{tr}$ & nd & $\operatorname{tr}$ \\
\hline 3 & Ethyl propanoate & $<800$ & Floral $^{\mathrm{b}}$, passion fruit $^{\mathrm{b}}$, green $^{\mathrm{b}}$ & 5,67 & 4,17 & 4,50 \\
\hline 4 & 3-methyl-1-butanol & $<800$ & Onion $^{c}$, gasoline ${ }^{c}$, rubber $^{c}$ & 0,25 & 0,32 & 0,52 \\
\hline 5 & 2-methyl-1-butanol & $<800$ & - & 0,15 & 0,11 & 0,49 \\
\hline 6 & 3-methylene-2-pentanone & $<800$ & - & 0,26 & 0,10 & 0,23 \\
\hline 7 & Ethyl isobutyrate & $<800$ & - & 0,27 & 0,11 & 0,10 \\
\hline 8 & Toluene & $<800$ & - & nd & $\operatorname{tr}$ & nd \\
\hline 9 & 1-pentanol & $<800$ & & $\operatorname{tr}$ & $\operatorname{tr}$ & $\operatorname{tr}$ \\
\hline 10 & 3-methyl-2-butenol & $<800$ & Cooked nut ${ }^{c}$ & 0,23 & 0,45 & 0,92 \\
\hline 11 & Ciclopentanone & $<800$ & - & 0,11 & 0,16 & 0,35 \\
\hline 12 & Butyric acid & $<800$ & - & 0,13 & 0,13 & 0,14 \\
\hline 13 & Ethyl butyrate & 803 & Pineapple $e^{\mathrm{a}, \mathrm{b}}$, passion fruit ${ }^{\mathrm{a}}$, fruity ${ }^{\mathrm{b}, \mathrm{c}}$, sweet $^{\mathrm{b}, \mathrm{c}}$, & 81,55 & 81,39 & 84,46 \\
\hline 14 & Furfural & 834 & Fresh garlic ${ }^{c}$, rubber $^{c}$, moldy $^{c}$ & 0,19 & 0,55 & 0,89 \\
\hline 15 & (E)-3-hexenol & 854 & Fruit $^{\mathrm{b}}$, guava $^{\mathrm{b}}$, passion fruit ${ }^{\mathrm{b}}$ & 0,34 & 0,36 & 0,30 \\
\hline 16 & (Z)-3-hexenol & 858 & Passion fruit ${ }^{\mathrm{b}}$, green ${ }^{\mathrm{a}, \mathrm{c}}$, herbal $^{\mathrm{b}, \mathrm{c}}$, unripe banana ${ }^{\mathrm{c}}$ & 0,43 & 0,38 & 0,27 \\
\hline 17 & 3-methylbutyric acid & 866 & - & $\operatorname{tr}$ & $\operatorname{tr}$ & $\operatorname{tr}$ \\
\hline 18 & 1-Hexanol & 874 & - & 1,16 & 1,35 & 1,37 \\
\hline 19 & 3-methylbutyl acetate & 880 & Fruit candy ${ }^{\mathrm{b}}$, tutti-frutti ${ }^{\mathrm{b}}$, floral ${ }^{\mathrm{b}}$ & 0,43 & 0,24 & nd \\
\hline 20 & 2-methylbutyl acetate & 882 & - & 0,14 & nd & nd \\
\hline 21 & 2-heptanone & 891 & - & nd & nd & nd \\
\hline 22 & Propyl butyrate & 899 & - & nd & nd & nd \\
\hline 23 & Benzaldehyde & 963 & Green $^{\mathrm{b}}$, herb $^{\mathrm{b}}$, green almond ${ }^{\mathrm{c}}$ & 0,90 & 0,85 & 0,82 \\
\hline 24 & Geranic oxide & 972 & - & 0,44 & 0,56 & 0,83 \\
\hline 25 & Heptanoic acid & 987 & 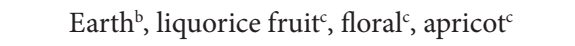 & $\operatorname{tr}$ & $\operatorname{tr}$ & $\operatorname{tr}$ \\
\hline 26 & $\mathrm{NI}$ & 990 & - & 0,38 & 0,44 & 0,49 \\
\hline 27 & Ethyl hexanoate & 1000 & Fruity $^{\mathrm{a}, \mathrm{b}, \mathrm{c}}$, floral $^{\mathrm{a}, \mathrm{b}}$, green $^{\mathrm{a}}$, sweet $^{\mathrm{b}}$, anise $\mathrm{s}^{\mathrm{b}, \mathrm{c}}$ & 1,16 & 1,19 & 1,12 \\
\hline 28 & 3-undecine & 1005 & - & 0,22 & 0,31 & 0,41 \\
\hline 29 & Hexyl acetate & 1015 & Perfume $^{a}$, floral ${ }^{a}$, fruity ${ }^{b, c}$, banana $^{c}$, cherry ${ }^{c}$ & 0,12 & 0,11 & nd \\
\hline 30 & Limonene & 1029 & Fresh $^{\mathrm{a}}$, floral ${ }^{\mathrm{a}}$, herbal $^{\mathrm{c}}$, fruity $^{\mathrm{c}}$ & 0,12 & 0,14 & 0,12 \\
\hline 31 & $(\mathrm{Z})$-ocimene & 1042 & Floral $^{c}$, rose $^{c}$, spicy $^{c}$ & $\operatorname{tr}$ & $\operatorname{tr}$ & $\operatorname{tr}$ \\
\hline 32 & a-methyl-bezenomethanol & 1062 & - & 0,15 & 0,45 & nd \\
\hline 33 & (Z)-linalool oxide & 1072 & - & 0,13 & 0,16 & 0,22 \\
\hline 34 & Terpinolene & 1084 & - & $\operatorname{tr}$ & $\operatorname{tr}$ & $\operatorname{tr}$ \\
\hline 35 & (E)-linalool oxide & 1087 & - & nd & $\operatorname{tr}$ & nd \\
\hline 36 & $\beta$-linalool & 1099 & Perfume $^{\mathrm{a}, \mathrm{b}}$, floral ${ }^{\mathrm{a}, \mathrm{b}, \mathrm{c}}$, lemon $^{\mathrm{b}, \mathrm{c}}$, fruity ${ }^{\mathrm{c}}$, sweet ${ }^{\mathrm{c}}$, & nd & $\operatorname{tr}$ & nd \\
\hline 37 & Benzoic acid & 1184 & - & nd & $\operatorname{tr}$ & $\operatorname{tr}$ \\
\hline 38 & 1-phenylethyl acetate & 1190 & Fruity $^{\mathrm{b}}$, perfume $^{\mathrm{b}}$, honey $^{\mathrm{b}}$ & nd & $\operatorname{tr}$ & $\operatorname{tr}$ \\
\hline 39 & Hexyl butyrate & 1193 & Toothpaste $^{c}$, fresh $^{c}$, medicinal $^{c}$, faint citrus-like ${ }^{c}$ & $\operatorname{tr}$ & $\operatorname{tr}$ & $\operatorname{tr}$ \\
\hline
\end{tabular}

RI: Retention Indices. NI: not identified. nd: not detected by FID. tr: trace amount (<0,01\%). $\Psi$ according to literature. ${ }^{\mathrm{a} J a l e s}$ et al. (2005); 'Jales (2005); ' Jórdan et al. (2002). 
Chen et al. (1982) and Jordán et al. (2002). Narain et al. (2004) reported ethyl propanoate, besides propyl butyrate, hexyl acetate and hexyl butyrate among the major compounds in Brazilian passion fruits.

Among the alcohols, 1-hexanol (1.16\%) was also considered a major compound. Several alcohols detected in the present work were previously reported in the literature: 1-pentanol, 1-hexanol, 3-methyl-1-butanol, (E)-3-hexen-1-ol and (Z)-3hexen-1-ol (JORDÁN et al., 2002; NARAIN et al., 2004).

It has already been widely demonstrated that the major volatile compounds are not necessarily the ones with the highest odoriferous importance. In olfactometric works with tropical fruits (GARRUTI et al., 2003; VALIM et al., 2003; JALES et al., 2005) many of the major compounds showed low odor intensities, and a great portion of the aromagram corresponded to peaks with little or no response at the instrumental detector (FID). Therefore, it is not very helpful to monitor major compounds if they do not bring considerable odoriferous contribution to the formation of passion fruit characteristic aroma and flavor. The most recent contributions on olfactometry of passion fruit juice are the works by Jordán et al. (2002), Jales (2005) and Jales et al. (2005) who have reported over 80 odoriferous compounds. Sandi et al. (2003) established positive correlations between esters ethyl butyrate, ethyl hexanoate, hexyl butyrate, hexyl hexanoate and the characteristic passion fruit aroma, as well as the sweet and floral aromas. The losses in the passion fruit-like and other contributor compounds can be correlated to the changes in the sensory profile. Besides, the increase in bad-odor compounds can also harm the product's quality.

Among all the odor-active compounds reported by those authors, eleven were detected in the passion fruit juice of this study in quantifiable amounts (Table 1), and therefore, were used to be monitored during storage: ethyl propanoate (described in the cited literature as passion fruit, floral, green), 3-methyl-1-butanol (smoky, overripe), 3-methyl-2butenol (cooked), ethyl butyrate (fruity, candy), (E)-3-hexenol (passion fruit, fruity), (Z)-3-hexenol (passion fruit, green), 3-methylbutyl acetate (tutti-frutti, floral), benzaldehyde (green), ethyl hexanoate (fruity, sweet), hexyl acetate (fruity, floral, perfume) and limonene (fruity, floral, fresh, herbal). Furfural (garlic, rubber) was also detected in the samples and was chosen to be monitored because it has been widely accepted as an indicator of flavor changes of fruit juices during the heating process i.e. concentration, pasteurization or storage (NAGY; RANDALL, 1973; BLANCO GOMIS et al., 1991).

Figure 1 shows relative areas (Area \%) concerning the eleven compounds monitored during the 120-day storage in glass bottled passion fruit juice samples. Ethyl butyrate is not in the figure because its relative area was too high to fit in the graphic's scale, but we can observe in Table 1, that ethyl butanoate showed a very small oscillation in the studied period. (E)-3-hexenol, benzaldehyde, ethyl hexanoate and limonene also showed no expressive variations (Figure 1). However, ethyl propanoate, (Z)-3-hexenol, 3-methylbutyl acetate and hexyl acetate showed to be sensitive to storage, the last was not even detected at the end of the storage time
(120 days). Ducruet et al. (2001), studying the preservation of aroma quality of strawberry syrup during shelf life (225 days) in different types of packaging materials (glass, PVC, and PET), observed that the decrease in the esters concentrations in glass bottles ranged from $40 \%$ - for ethyl 2-methylbutyrate, ethyl 3-methylbutyrate, 3-methylbutyl 3-methylbutyrate - to $80 \%$ for ethyl butyrate, hexyl acetate, 3-(E)-hexenyl acetate and octyl acetate. The authors stated that the general decrease in ester concentrations could be explained by their hydrolysis and formation of the corresponding acids and alcohols. In fact, in the present work we observed an increase in the corresponding alcohol of ester 3-methylbutyl acetate (3-methyl-1-butanol) and hexyl acetate (hexanol). We were not able to detect the corresponding alcohol of ethyl propanoate (ethanol), but it could be together with the solvent peak, since its retention index in the DB-5 column (668) is lower than the first peak detected (pentanal, 732).

Other alcohols did also increase. Chassagne et al. (1999), evaluating glicosidically bound volatile compounds in Passiflora edible fruits, found important concentrations of bound alcohols such as 3-methyl-2-butenol and 2-methyl-1butanol. The cleavage of the glicosidic bounds in such an acidic medium during storage and the release of those alcohols could explain the increase of their amounts in the juice.

Saint-Eve et al. (2008) studying the effect of packaging (glass, polystyrene and polypropylene) also observed a decrease of aroma compounds in flavored yoghurt stored in glass jars for 28 days, mainly hexanal, esters ethyl hexanoate, ethyl acetate, ethyl butyrate, methyl cinnamate and terpenes limonene and linalool.

A small amount of furfural was detected in the juice at the beginning of storage, which increased with time. Lee and Nagy (1988), studying commercial canned grape fruit juices

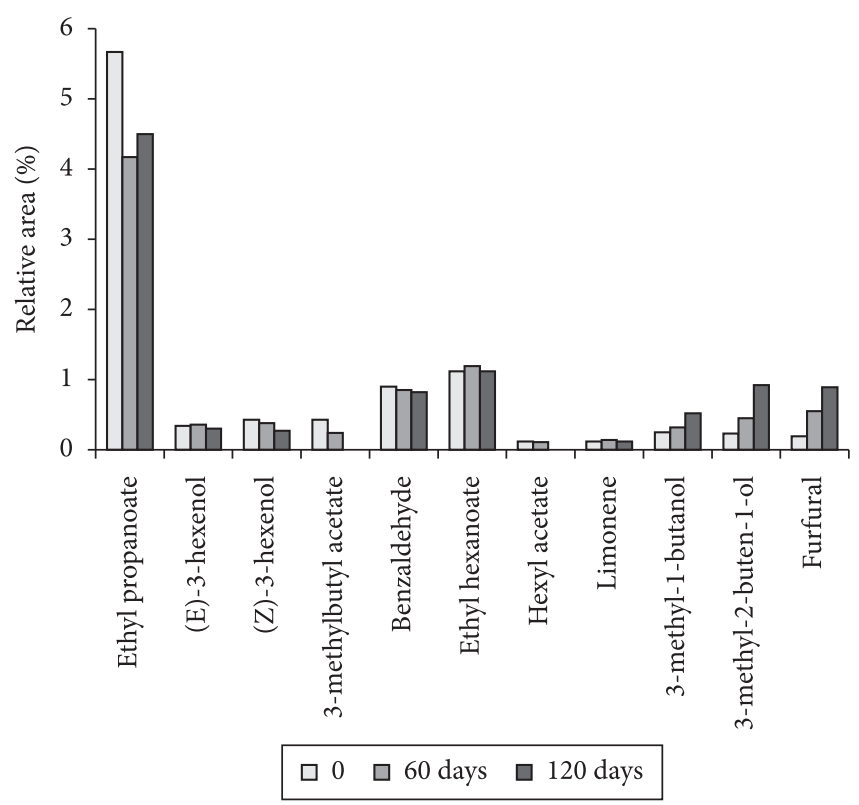

Figure 1. Selected odor-active volatiles of passion fruit juices stored in glass bottles for 120 days. 
Table 2. Effect of storage time on sensory attributes ( $p$ values and intensity means) for passion fruit juice in glass bottles.

\begin{tabular}{ccccccc}
\hline Sensory attribute & $\mathrm{p}$ value & \multicolumn{5}{c}{ Intensity } \\
\cline { 3 - 7 } & & 0 & 30 & 60 & 90 & 120 \\
\cline { 3 - 6 } & & $4.80^{\mathrm{a}}$ & $4.61^{\mathrm{a}}$ & $4.49^{\mathrm{a}}$ & $4.47^{\mathrm{a}}$ & $4.80^{\mathrm{a}}$ \\
& 0.92 & $5.13^{\mathrm{a}}$ & $4.62^{\mathrm{a}}$ & $4.46^{\mathrm{a}}$ & $4.69^{\mathrm{a}}$ & $4.70^{\mathrm{a}}$ \\
\hline Aroma & 0.44 & ${ }^{2}$ &
\end{tabular}

stored in different temperatures during 15 weeks, observed that a temperature elevation from $10{ }^{\circ} \mathrm{C}$ to $40^{\circ} \mathrm{C}$ induced a 390 -fold increase in furfural content at the end of the storage time. In the present study the juices were stored at temperatures varying from 23 to $28^{\circ} \mathrm{C}$, which favored the rapid formation of furfural in the passion juice samples.

Despite these flavor compounds variations, storage time had no effect on the sensory characteristics of passion fruit juice storage in glass bottles over 120 days storage, as shown by the two-way ANOVA (Table 2). As both sensory attributes (aroma and flavor) did not vary significantly between the beginning and the end of the storage period, the linear regressions were not calculated. This behavior can be explained by the predominance of ethyl butyrate in the sample (additional flavoring), which masked possible subtle sensory variations. Besides, although furfural did increase, it is known that its aroma threshold is rarely exceeded, even in juice that had suffered temperature abuse (PEREZ-CACHO; ROUSEFF, 2008).

\section{Conclusions}

Most of the odor-active compounds important to the characteristic fresh passion fruit flavor underwent small or no changes during the 120-day storage. Nevertheless, some of them, namely ethyl propanoate, Z-3-hexen-1-ol and 3-methylbutyl acetate, slightly suffered the effects of biochemical reactions that occurs in such an acidic matrix. Some alcohols and furfural derived from degradation processes did increase, but the trained panel did not perceive impairment in the sensory quality of the juice during the studied period.

\section{Acknowledgements}

The authors wish to acknowledge the sensory panel at Embrapa Tropical Agroindustry research center. The first author would like to thank FUNCAP (Fundação Cearense de Amparo à Pesquisa) for the post-graduate fellowship grant.

\section{References}

AZEREDO, H. M. C.; FARIA J. A. F.; BRITO, E. S. Embalagens e estabilidade de alimentos. In: AZEREDO, H. M. C. (Ed). Fundamentos de Estabilidade de Alimentos. Fortaleza: Embrapa Agroindústria Tropical, 2004. 151 p.

BAHIA (Estado). Secretaria de Agricultura, Irrigação e Reforma Agrária. Cultura - Maracujá. Disponível em: <http://www.seagri. ba.gov.br/Maracuja.htm>. Acesso em: 19 ago. 2008.

BAHIA (Estado). Secretaria de Agricultura, Irrigação e Reforma Agrária. O doce sabor do maracujá. Disponível em: <http://www. seagri.ba.gov.br/noticias.asp?qact=view\&exibir=clipping\&not $\mathrm{id}=10287>$. Acesso em: 10 set. 2007.

BLANCO GOMIS, D. et al. High-performance liquid chromatographic determination of furfural and hydroxymethylfurfural in apple juices and concentrates. Chromatographia, v. 32, p. 45-48, 1991. http:// dx.doi.org/10.1007/BF02262465

CHANSSAGNE, D.; BOULONGER, R.; CROUZE, J. Enzymatic hydrolysis of edible Passiflora fruit glycosides. Food Chemistry, v. 66, n. 3, p. 281288, 1999. http://dx.doi.org/10.1016/S0308-8146(99)00044-8

CHEN, C. C. et al. Headspace components of passion fruit juice. Journal Agricultural Food Chemistry, v. 30, n. 6, p. 1211-1215, 1982. http://dx.doi.org/10.1021/jf00114a052

DAMÁSIO, M. H.; COSTELL, E. Análisis sensorial descriptivo: generación de descriptores y seleción de catadores. Revista Agroquímica Tecnologia Alimentos, v. 31, p. 165-178, 1991.

DUCRUET, V. et al. Influence of packaging on the aroma stability of strawberry syrup during shelf life. Journal Agricultural Food Chemistry, v. 49, n. 5, p. 2290-2297, 2001. PMid:11368591. http:// dx.doi.org/10.1021/jf0012796

FERRARI, R. A.; COLUSSI, F; AYUB, R. A. Caracterização de subprodutos da industrialização do maracujá - aproveitamento das sementes. Revista Brasileira Fruticultura, v. 26, n. 1, p. 101-102, 2004. http://dx.doi.org/10.1590/S0100.294.5200400.010.0027

FRANCO, M. R. B.; RODRIGUEZ-AMAYA, D. B. Trapping of soursop (Annona muricata) juice volatile on Porapak Q by suction. Journal Science Food Agriculture, v. 34, n. 3, p. 293-299, 1983. http://dx.doi. org/10.1002/jsfa.274.034.0313

GARRUTI, D. S. et al. Evaluation of volatile flavour compounds from cashew apple (Anacardium occdientale L) juice by the Osme gas chromatography / olfactometry technique. Journal Science Food Agriculture, v. 83, n. 14, p. 1455-1462, 2003. http://dx.doi. org/10.1002/jsfa. 1560

GONÇALVES, J. S.; SOUZA, S. A. M. Fruta da paixão: Panorama Econômico do maracujá no Brasil. Informações Econômicas, v. 36, n. 12, 2006. Disponível em: <http://www.iea.sp.gov.br/out/verTexto. php? codTexto=8261>. Acesso em: 9 ago. 2008.

GRAUMLICH, T. R.; MARCY, J. E.; ADAMS, J. P. Aseptically packaged Orange juice and concentrate: a review of the influence of processing and packaging conditions on quality. Journal Agricultural Food Chemistry, v. 34, n. 3, p. 402-405, 1986. http://dx.doi.org/10.1021/ jf00069a004

JALES, K. A. Efeito do processamento sobre os constituintes voláteis do suco de maracujá. 2005. 34 f. Dissertação (Mestrado em Tecnologia de Alimentos)-Faculdade de Engenharia de Alimentos, Universidade Federal do Ceará, Fortaleza, 2005.

JALES, K. A. et al. Evaluación de los compuestos odoríferos del jugo de maracuyá amarillo por GC-MS y GC-O (OSME). Noticias Técnicas Laboratorio, v. 3, p. 12-14, 2005.

JORDÁN, M. J.; GOODNER, L. K.; SHAW, P. E. Characterization of the aromatic prolife in aqueous essence and fruit juice of yellow passion fruit (Passiflora edulis Sims F. Flavicarpa degner) by GC-MS and CG/O. Journal Agricultural Food Chemistry, v. 50, p. 1523-1528, 2002. http://dx.doi.org/10.1021/jf011077p

LEE, H. S.; NAGY, S. Quality changes and nonenzymic browning intermediates in grapefruit juice during storage. Journal Food Science, v. 53, p. 168-172, 1988. http://dx.doi. org/10.1111/j.1365-2621.1988.tb10201.x

MEILGAARD, M.; CIVILLE, G. V.; CARR, B. T. Sensory Evaluation Techniques. Boca Raton: CRC Press, 1999. p. 43-57. http://dx.doi. org/10.1201/978.143.9832271

NAGY, S.; RANDAL, V. Use of Furfural Content as an Index of Storage Temperature Abuse in Commercially Processed Orange Juice. 
Journal Agricultural Food Chemistry, v. 21, n. 2, p. 272-275, 1973. http://dx.doi.org/10.1021/jf60186a025

NARAIN, N. et al. Compostos voláteis dos frutos de maracujá (Passiflora edulis forma Flavicarpa) e de cajá (Spondias mombin L.) obtidos pela técnica de headspace dinâmico. Ciência e Tecnologia de Alimentos, v. 24, n. 2, p. 212-216, 2004. http://dx.doi.org/10.1590/ S0101.206.1200400.020.0009

PEREZ-CACHO, P. R.; ROUSEFF, R. Processing and storage effects on Orange juice aroma: A Review. Journal Agricultural Food Chemistry, v. 56, n. 1, p. 9785-9796, 2008. PMid:18828595. http:// dx.doi.org/10.1021/jf801244j
SAINT-EVE, A. et al. Quality changes in yogurt during storage in different packaging materials. Food Chemistry, v. 110, n. 2, p. 285-293, 2008. http://dx.doi.org/10.1016/j.foodchem.2008.01.070

SANDI, D. et al. Correlações entre características físico-químicas e sensoriais em suco de maracujá-amarelo (Passiflora edulis var. flavicarpa) durante o armazenamento. Ciência e Tecnologia de Alimentos, v. 23, n. 3, p. 355-361, 2003. http://dx.doi.org/10.1590/ S0101.206.1200300.030.0010

VALIM, M. F.; ROUSEFF, R. L.; LIN, J. Gas ChromatographicOlfactometric Characterization of Aroma Compounds in Two Types of Cashew Apple Nectar. Journal Agricultural Food Chemistry, v. 51, n. 4, p. 1010-1015, 2003. PMid:12568564. http://dx.doi. org/10.1021/jf025738+. 